\title{
The Impact of Fashion Entrepreneurs' Traits on the Success of Fashion Businesses in the Gauteng Province In South Africa
}

\author{
Prof KC Moloi \\ Vaal University of Technology, Faculty of Human Sciences \\ Vanderbijlpark, 1900, South Africa \\ Email:conniem@vut.ac.za
}

Ms MA Nkhahle-Rapita

tselinkhahle@webmail.co.za

Doi:10.5901/mjss.2014.v5n4p78

\begin{abstract}
The aim of this article is to examine the impact of fashion entrepreneurs' traits on the success of fashion businesses in the Gauteng province of South Africa. Entrepreneurs are said to be individuals who accept risks and who are innovative in terms of their business management skills, while displaying the personal traits of risk taking, creativity, ambition and other qualities involved in the provision of products and services to society. We argue that entrepreneurs are important because they contribute to the economy of the country. The research design employed for the study was quantitative, using a selfadministered questionnaire to elicit information on the impact of fashion entrepreneurs' traits on the success of the fashion businesses from respondents in the industry. The study found that 92.3 percent of fashion entrepreneurs take risks while 100 percent indicated that they were motivated by the success achieved in their businesses. Some of the fashion entrepreneurs (75.9 percent) indicated that they considered themselves to be creative.
\end{abstract}

Keywords: Entrepreneurship, fashion entrepreneurs, traits, success, Vaal region

\section{Introduction}

This quantitative study looks at the impact of fashion entrepreneurs' traits on the success of fashion businesses in the Gauteng province of South Africa. Studies on successful entrepreneurship indicate that entrepreneurship may be determined by psychological factors such as risk taking, self-confidence, ambition, motivation, positive attitude, creativity and innovation, opportunity orientation and business commitment (Ehigie \& Umoren 2003:79). Some of these factors, particularly the psychological factors, are grounded in social action theory (Silverman 1970), economic theories (Martin 1979) and human capital theory (Becker 1964). The social action theory of Silverman (1970) holds that the goals of the individual and the means selected and actions taken to achieve particular goals are affected by the individual's perception of the situation. Social action theory looks to the individual's own definition of the situation as a basis for explaining a particular behaviour. The rationale for this study is to investigate the impact of fashion entrepreneurs' traits on their perceptions of business success and how this influences their entrepreneurial behaviour. Among the studies that have been conducted on the impact of entrepreneurs' traits on business success, there is no evidence of defined psychological parameters for quantifying business success. The literature shows that there are, rather, individual differences in the perception of business success and that how an individual interprets success determines whether she will be satisfied with and well-adjusted to business performance (Ehigie \& Umoren 2003:79-80).

Economic theories of entrepreneurship, on the other hand, view the contribution of the entrepreneur as the creator of a new enterprise, clearly establishing an outcome-based approach to understanding the running of a business (Prakash \& Ouma 2013:96). However, the economics stream continues to be in need of effective operationalisation. For example, articles advocating economic theories of entrepreneurship often leave the empirical tests to future research. While economic theories have been useful in helping to identify what entrepreneurship is and when it occurs (Mitchell 2004:166), they have been less helpful in explaining the entrepreneurs' traits that contribute to the success of the business.

Much entrepreneurship research into human capital has given priority to personality traits and demographic 
characteristics (Littunen 2000; McCarthy \& Leavy 1999; Cooper, Gimeno-Gascon, \& Woo 1994). Human capital corresponds to any stock of knowledge or characteristics of the worker (either inherent or learnt) that contribute to his or her productivity (Becker 1964). This theory is also concerned with the role of an individual's investments in education, knowledge, skills and abilities and how this enhances cognitive abilities that can result in more productive activities. Capital is perceived as an umbrella term for critical assets - human, social and economic. It can be strongly influenced either positively or negatively by the decisions and achievement of the entrepreneur (Prakash \& Ouma 2013:97). For the purpose of this study, the emphasis is on the contribution of personality traits to the success of fashion businesses.

\section{Problem Statement}

Many studies have been conducted on the extent of business ownership and control of business. Much literature focuses on entrepreneurship issues in demographic studies related to specific industries and individuals involving entrepreneurship ventures. There is scant research on specific entrepreneurship issues in the Vaal region of South Africa. Some researchers have studied entrepreneurship in countries such as Kenya and Uganda and this literature has ventured to test gender and microfinance issues. The researchers found no study on whether entrepreneurs' traits have any impact on the success of fashion businesses. There are few studies which have analysed whether personality traits have an impact on business operations (Littunen 2000; Merrett \& Gruidi 2000; Olson 2000; Deamer \& Earle 2004; Vallone 2008). The researchers did not find any literature investigating the impact of fashion entrepreneurs' traits on the success of fashion businesses in South Africa. This prompted the researchers to address this gap by undertaking this study.

This study could contribute to a better understanding of entrepreneurship in the Vaal region and could be of value to academics as well as fashion entrepreneurs in terms of useful information for future entrepreneurs interested in participating in the fashion or clothing sector. There is a great need in the Vaal region to focus studies on fashion entrepreneurs because of the level of poverty among communities which live in informal settlements (those settlements which are not in the statutory laws of the country) and in the black communities residing outside the more advanced suburbs.

\section{Objectives of the Study}

The objective of this study was to investigate the impact of risk taking, self-confidence, ambition, motivation, positive attitude, creativity, opportunity recognition and commitment on the success of fashion entrepreneurs in the Vaal region of South Africa.

\subsection{Primary objectives}

To investigate the impact of fashion entrepreneurs' traits on the success of fashion businesses

\subsection{Theoretical objective}

An in-depth literature review was undertaken to investigate the impact of risk taking, self-confidence, ambition, motivation, positive attitude, creativity, opportunity recognition and commitment on entrepreneurs.

\subsection{Empirical objective}

The empirical objective of this study was to administer a questionnaire in order to describe the impact of fashion entrepreneurs' traits on the success of fashion businesses.

\section{Research Question}

The research question was stated as follows:

- What is the impact of fashion entrepreneurs' traits on the success of the fashion businesses? 


\section{Literature}

In this section of the study, the researchers present a literature study on the impact of fashion entrepreneurs on the success of the fashion business in the Vaal region of Gauteng province in South Africa.

\subsection{Traits of fashion entrepreneurs}

The literature on entrepreneurship can be classified as investigating the classical role or the psychological role, as viewed by economists and behavioural scientists respectively. This paper embraces the behavioural definition of the entrepreneur, which defines the term with regard to his/her personality traits or characteristics. The trait theory of entrepreneurship contends that certain attitudinal and behavioural factors differentiate successful entrepreneurs from the unsuccessful. Basically, this approach emphasises the importance of the individual entrepreneur to the formation and success of a business. The term "entrepreneur" is subject to a great deal of definitional and operational ambiguity. Entrepreneurs are said to be individuals who accept risks and who are innovative in terms of their business management skills, while displaying the personal traits of risk taking, creativity, ambition and other qualities involved in the provision of products and services to society (Littunen 2000:295; Marshall et al. 2000:172; Turner 2005:264). Entrepreneurial traits refer to the most notable characteristics or behaviour associated with an entrepreneur (Burke 2008:29).

Fashion entrepreneurs are people who focus on selling fashion-related products such as shoes, accessories, wedding gowns, matric farewell gowns and evening garments, as well as curtains and other attractive products in the field of fashion (Burke 2008:12). Fashion entrepreneurs have distinctive character traits even though the mix and emphasis of these traits are certainly different for each entrepreneur (Burns 2007:35). Entrepreneurial traits can be inherited from the entrepreneur's parents or be learned at school (Burns 2007:30; Kuratko 2009:05). Such traits have been researched and evaluated in various studies, for example, by Littunen (2000:304), and are related to the success of entrepreneurs. The findings of the study by Littunen (2000) concluded that entrepreneurship and the traits of entrepreneurs should not be studied separately as these traits are characteristics inseparable from a successful entrepreneur.

The role of entrepreneurial personality traits has also been taken into consideration by Olson (2000). The study provides a fresh look at entrepreneurial traits and the results suggest that such traits are associated with an ability to start and run a successful business. The controversial role of personality traits in entrepreneurial psychology is discussed in an article by Llewellyn and Wilson (2003). In the article, entrepreneurial traits such as risk taking, creativity and ambition are discussed. However, Llewellyn and Wilson (2003:342) criticise the use of psychometric measures of personality traits as their reliability and validity are unknown or unacceptable. According to Deamer and Earle (2004), there is a psychometric tool called Enterprising Managers Assessment Questionnaire (EMAQ) that is used to test people leaning towards entrepreneurship. EMAQ gives insight into whether a person might succeed as an entrepreneur. Because this study does not focus on leaning towards entrepreneurship, the EMAQ questionnaire was not used for this study.

Entrepreneurial traits are associated with the drive for the success of the business (Yueh 2009:782). In the challenging world of entrepreneurship, chances of success increase dramatically if the prospective entrepreneur begins by understanding who he or she is (Granger \& Sterling 2003:5). The traits of fashion entrepreneurs, such as risk taking, self-confidence, ambition, motivation, positive attitude, creativity and innovation, opportunity orientation and commitment are perceived to be related to the success of the business (Littunen 2000:295; Olson 2000:5; Granger \& Sterling 2003:5, Van Gelderen Thurik \& Bosma 2005:367).

\subsubsection{Risk taking}

The word risk has a slightly negative connotation as it implies danger, tension and possible loss (Kuratko 2009:34). Risk taking is a central part of any business because starting a new business is the first risk, with many more to come as the business grows (Krauss, Frese \& Friedrich 2005:321). Entrepreneurs are not afraid to use their personal money for the business, with no guarantee of profit (Vallone 2008:190). They intelligently examine the type of risk before making a decision. After examining the type of risk, if entrepreneurs believe that it is reasonable and can lead to the goal they want to achieve, they take the risk (Smit 2000:6). Successful entrepreneurs are willing to take risks in order to accomplish their objectives (Fatt 2001:79). 


\subsubsection{Self-confidence}

Self-confidence means the ability of entrepreneurs to trust their own judgement. It is the belief that the entrepreneur has the ability to apply the necessary personal skills and capabilities to achieve a certain level of success in running the business. Entrepreneurs with self-confidence in a project they are pursuing persevere through setbacks, aim higher, and develop better plans and strategies for the task. They take negative feedback in a positive manner and use that feedback to improve the performance of their businesses (Shane, Locke \& Collins 2003:276). Although entrepreneurs are faced with several obstacles, such as sources of finance during business start-up and lack of business skills, belief in themselves never fades. Entrepreneurs maintain their confidence and let those around them know it (Burns 2007:37; Kuratko 2009:36). Success in fashion entrepreneurship requires self-confidence (Van Praag 2003:4).

\subsubsection{Ambition}

Ambition is another trait of entrepreneurs, according to a theory developed by McClelland in 1961, and can be expressed as a need to achieve, as stated by Littunen (2000:296). Ambition influences the extent to which entrepreneurs strive to create something that is important and significant. It also influences the extent to which entrepreneurs pursue opportunities. The nature of entrepreneurial ambition is to make money or the need to create something new by turning an idea to into reality. Ambition is signified by setting goals because entrepreneurs are driven by the desire to compete, to excel against self-imposed standards and to pursue challenging goals and get positive results (Olson 2000:06; Shane et al. 2003:268; Kuratko 2009:32).

\subsubsection{Motivation}

Motivation is the determinant of behaviour that makes people aware of their needs and inspires action. Motivation is required for entrepreneurs to be successful in entrepreneurship before starting an entrepreneurial business (Van Praag 2003:4). Satisfying a need in a particular manner also motivates people (Cronje, Du Toit \& Motlatla 2001:154,156). Motivation is related to learning, internal locus of control and supports active striving to reach goals (Littunen 2000:296). Entrepreneurs believe in themselves. They believe that their accomplishments are within their own control and influence. This characteristic of an entrepreneur is linked with achievement, motivational drive, desire to take personal responsibility and self-confidence (Kuratko 2009:32).

Furthermore, successful entrepreneurs are motivated by their ability to take risks and to believe in themselves as well as in what they produce. This is termed internal locus of control, which is important to fashion entrepreneurs, who need to be able to convince clients of the value of their work or ideas (Fatt 2001:80). Internal locus of control in an entrepreneur refers to one's ability to control one's behaviour or character by evaluating one's own actions (Littunen 2000:296; Olson 2000:6).

\subsubsection{Positive attitude}

The way a person communicates his/her mood to other people is called attitude. For instance, when a person is optimistic and anticipates successful encounters, a positive attitude is transmitted and other people usually respond favourably. The manner in which a person makes a judgement, whether it is positive or negative, is called an attitude. A positive attitude gives the courage to address a problem and take action to resolve it before it gets out of hand. Even if there is no ideal solution, a person's attitude can help him/her to live with the problem in a way which will help to neutralise its negative impact. Many talented people who can become successful entrepreneurs with desirable traits remain lonely and unhappy because they do not realise the importance of a positive attitude. The ability to combine expectations with quick recovery when setbacks occur is the secret of successful entrepreneurship (Chapman 1987:11).

A positive attitude is the outward manifestation of the mind that dwells primarily on positive matters. It is a mind-set tipped in favour of creative activity rather than boredom. The more entrepreneurs can focus on positive thinking about the business, the easier it will be to remain positive and successful (Chapman 1987:11, 13, 14, 19). Entrepreneurs should have a positive attitude towards their business so that they may be able to accomplish their desired goals. Maintaining a positive attitude requires that fashion entrepreneurs have determination and an understanding of their role in the business (Vallone 2008:22). Entrepreneurs with a positive attitude towards their business make sure that people around them think positively so that clients will enjoy doing business with them. This is an important trait that contributes to the 
leadership and success of the entrepreneurial business (Nieman, Hough \& Nieuwenhuizen 2003:16).

\subsubsection{Creativity and innovation}

In entrepreneurship, creativity generally refers to the desire to change the ways in which products are made by entrepreneurs, which results in innovation (McDaniel 2002:5). Creativity is defined in this case as the making of novel products by generating new ideas as well as solving problems (Amabile, Barsade, Mueller \& Staw 2005:368). In fashion entrepreneurship, creativity requires knowledge, motivation, an encouraging environment, creative thinking styles and appropriate personality traits (Sinha 2002:2-3). Creative ideas can originate at any time and anywhere for fashion entrepreneurs (Paksoy \& Yalcin 2005:1). For example, ideas may emerge when fashion entrepreneurs make use of fashion magazines to check the latest styles and designs or after having attended a fashion show (Mete 2006:283). The implementation and development of creative ideas is called innovation (Ward 2004:174). In the context of fashion entrepreneurship, creativity and innovation is about making sure that fashion entrepreneurs generate valuable ideas for new products that will be demanded by their clients (Ward 2004:174). The success of a business is determined by the degree to which good ideas are generated, developed and implemented. Creativity leads to innovation, which then brings change in the business. The change could be a new product, service or technique of managing the business (Nieman et al. 2003:15).

\subsubsection{Opportunity recognition}

Opportunity recognition refers to the regular awareness of opportunities that exist in everyday life. Entrepreneurs focus more on the opportunity than on resources, structure or strategy. They set attainable goals that enable them to focus on opportunities. Entrepreneurs start with an opportunity and let their understanding of an opportunity guide other important issues within the business. The recognition ingredient helps entrepreneurs to define priorities and provides them with measures of how well they are performing (Scarborough \& Zimmerer 2003:9; Kuratko 2009:32).

\subsubsection{Commitment}

According to Fink, Harms and Kraus (2008:430), commitment is the willingness of entrepreneurs to be engaged in their businesses by working hard as well as sacrificing their family time and money and reducing their standard of living. Kuratko (2009:32) noted that being committed to succeed in entrepreneurial businesses helps entrepreneurs to overcome barriers such as insufficient financial backup. Commitment can be achieved by entrepreneurs working together in order to gain economic benefit. It can also help in the operation and performance of the business (Fink et al. 2008:430). Scarborough and Zimmerer (2003:9) add that commitment helps entrepreneurs to overcome mistakes that threaten the business, such as not attending to clients' orders, as well as obstacles that might hamper the growth of the business. For the purpose of this study, commitment refers to the engagement of fashion entrepreneurs in achieving business success as well as to their eagerness to achieve such success. The positive effect of commitment in entrepreneurial businesses is noted by several authors, including Shane et al. (2003:259); Lau, Shaffer and Au (2007:131) and Kuratko (2009:32).

\section{Research Design and Methodology}

The research design for the study was a quantitative method of investigation, using a descriptive exploratory questionnaire to find information regarding fashion entrepreneurs' traits. The focus was on gathering demographic information about fashion entrepreneurs and eight selected traits: risk taking, self-confidence, ambition, motivation, positive attitude, creativity, opportunity recognition and commitment. This was achieved by means of an intervieweradministered questionnaire. This approach was used because it allows the researcher to clarify certain questions that the respondents may not understand (Babbie \& Mouton 2001:80; Babbie 2010:274). The quantitative method was chosen because it satisfies the researcher's interest in and desire for better understanding of the phenomenon under investigation (Babbie \& Mouton 2001:80). It is objective and explains phenomena by collecting numerical data that are analysed using mathematically based methods (Creswell 2009:12). Moreover, it is also an economical method of data collection and the researcher has a neutral approach to the study (Delport 2005:159). 


\subsection{Target population}

Fashion entrepreneurs in the Vaal region who can construct and sew clothes and curtains made up the sample for this study.

\subsection{Sample frame}

The researchers obtained a complete list of all members of the population from which a sample for the study would be selected (Babbie 2010:197). This list of 144 fashion entrepreneurs was obtained from Van Wyk (2007) and 164 fashion entrepreneurs from Vaal Wed organisation (the organisation for fashion entrepreneurs who sew wedding gowns in the Vaal region). This sampling frame facilitated access to the selected sampling units (units of analysis, that is fashion entrepreneurs who can sew clothes and curtains), and all units were given a logical and numerical identifier to make sure that every element of the population of interest was present in the sampling frame. Only 208 fashion entrepreneurs took part in the study.

\subsection{Sampling method}

Owing to the quantitative nature of this study, the simple random sampling technique was used to select 208 respondents. This method was used because it is the least biased of all sampling techniques, as there is no subjectivity. Each member of the total population has an equal chance of being selected (Babbie and Mouton 2001: 271). It results in a sample highly representative of the population of interest, which simplifies data interpretation and analysis of the results. While the randomness of the selection process ensures the unbiased choice of subjects, it could also by chance lead to the assembly of a sample which does not represent the population well. This random variation independent of all human bias and in many cases difficult to pinpoint is known as sampling error. The probability of incurring errors in sampling increases with decreased sample size. The researchers therefore set a sample size big enough to minimise the likelihood of freak results (Creswell 2009:146).

\subsection{Data collection}

The study relied primarily on the survey method. A survey instrument was developed to capture the information relating to the research objectives. A structured questionnaire was constructed to measure the variables, using a five-point Likertscale anchored by "strongly disagree" and "strongly agree". The questionnaire was a self-administered questionnaire distributed to fashion entrepreneurs.

\subsection{Data analysis}

The quantitative data were captured by the researcher. The SPSS (Statistical Package for Social Sciences) version 17.0 was used to analyse the data, which were analysed in the numeric form of analysis, using descriptive analysis. The analysis was conducted to identify mean scores, standard deviations and range scores for the variables and ranking order (Creswell 2009:152).

\section{Findings and Discussion}

Entrepreneurial traits are associated with the drive for the success of the business (Yueh 2009:782). Eight prominent entrepreneurial traits were selected from the literature and used for this paper. These traits include risk taking, selfconfidence, ambition, motivation, positive attitude, creativity, opportunity recognition and commitment. Fashion entrepreneurs in this study (92.3 percent) agreed that they took risks by working more than eight hours per day in order to see their businesses growing and making a profit, which is a signal for business success. Risk taking is considered to be a personal trait that contributes towards the success of fashion entrepreneurs because starting a business requires entrepreneurs to take risks. This is also supported by Krauss et al. (2005:321). Ninety percent of the respondents strongly agreed with all the statements used in the questionnaire to measure the fashion entrepreneurs' traits, except for creativity (75.9 percent), which might indicate that fashion entrepreneurs in the Vaal region lack creative skills. Entrepreneurs with self-confidence take negative feedback in a positive manner and use that feedback to improve the 
performance of their businesses (Shane et al. 2003:276). Therefore, the respondents of this study (90.8 percent) strongly agreed with Shane et al. (2003:276; Van Praag 2003:4).

According to Littunen (2000:296), motivation is related to learning and internal locus of control, and supports active striving to reach goals. All the respondents (100 percent) of this study indicated that they are motivated by reaching their goals of making a profit. The respondents (100 percent) agreed/strongly agreed that they are ambitious to see their businesses growing and they have the drive to achieve. Chapman (1987:11-19) suggests that entrepreneurs should continue to think positively about their businesses because it is easier to remain successful when one is positive. Positive thinking makes it easier for fashion entrepreneurs to be successful (Nieman et al. 2003:16). All the statements measuring positive attitudes in the questionnaire of this study scored 99 percent and more, indicating that the fashion entrepreneurs of this study are indeed positive about the success of their businesses. Creativity is about making sure that fashion entrepreneurs generate valuable ideas for new products that will be demanded by their clients (Ward 2004:174). However, the results confirm that only 75.9 percent of the fashion entrepreneurs in this study are creative. More than 90 percent of the respondents agreed that they recognise opportunities that might contribute to the growth of their businesses. Entrepreneurs make personal sacrifices and extraordinary efforts to accomplish a task (Nieman et al. 2003:17). The respondents (99.5 percent) responded positively to all the statements that measured commitment.

Regarding the difference between the traits of male and female fashion entrepreneurs, this study found that the traits are not significantly different, except for self-confidence. It seems that male fashion entrepreneurs are more confident than female fashion entrepreneurs regarding the performance of the business. Vázquez-Carrasco et al. (2011:15) also noted that female entrepreneurs are less self-confident than their male counterparts even though success in fashion entrepreneurship requires self-confidence (Van Praag 2003:4).

\section{Limitations of the Study}

This study includes only fashion entrepreneurs located in Vanderbijlpark and surrounding townships. No other townships that are part of the Vaal region were included. Therefore, the results might not be representative of all fashion entrepreneurs in the Vaal region. The researcher also did not look at any other personal traits that could impact the success of fashion entrepreneurs.

\section{Ethical Considerations}

Ethical considerations were adhered to in this study, which involved agreements between the researchers and the selected respondents (Babbie \& Mouton 2001:520). These agreements observed voluntary participation, as suggested by Coertze (1999:178), Creswell (2009:89) and Babbie (2010:64), which allowed respondents to contribute or not to contribute to the study voluntarily (Babbie \& Mouton 2001:521). The researchers kept in mind that no harm should be done to respondents (Creswell 2009:89; Babbie 2010:64). Questions relating to personal characteristics of the fashion entrepreneurs that would be humiliating or make participants feel uncomfortable, such as their bank statements, were also avoided, (Babbie \& Mouton 2001:522; Creswell 2009:89; Babbie 2010:66). The interests of the respondents taking part in the study were protected by not revealing their identities (Babbie \& Mouton 2001:523; Maree \& Van der Westhuizen 2007:42). The anonymity and confidentiality of the results and findings of the study also protected the respondents' identities, as suggested by Maree \& Van der Westhuizen (2007:42). Moreover, the authors believe that misleading the respondents is unethical and therefore the true purpose of conducting the research was communicated to them (Babbie \& Mouton 2001:525 -526; Creswell 2009:89; Babbie 2010:67-70).

\section{Recommendations for Future Research}

The study was not representative of all fashion entrepreneurs in the Vaal region. It is recommended that future research should include all fashion entrepreneurs in the region. Other researchers are encouraged to look at any other personal traits that could have an impact on the success of fashion entrepreneurs in the Vaal region. Fashion entrepreneurship is an important unit contributing to the economic growth of the country since the small and medium business sector will attract and create jobs for many more South Africans. 


\section{Conclusion}

In the study referred to in this paper the authors argued that, with the advent of democracy in South Africa since 1994 and the ascendency to political power of the African National Congress (ANC), many transformations in the socio-political and economic spheres took place with a view to addressing the imbalances of the past inherited from the segregationist regime of the National Party (NP). We discussed the transformation agenda in the country and showed that its intention has been to address the challenges inherited form the past segregationist regime through entrepreneurship and the enhancement of small businesses. The authors argued that the focus on entrepreneurship is aimed at creating more jobs for the unemployed among South Africans in order to improve their livelihoods and simultaneously contribute to the country's GDP. We argued that fashion entrepreneurs are significant because of their impact on the growth of small businesses in the country.

\section{Reference}

Amabile, M.T., Barsade, G.S., Mueller, J.S. \& Staw, B.M. (2005). Affect and creativity at work. Administrative Science Quarterly, 50,367403.

Babbie, E. \& Mouton, J. (2001). The practice of social research. Cape Town: Oxford University Press.

Becker, G. S. (1964). Human capital. New York: Columbia University Press.

Babbie, E. (2010). The practice of social research. $12^{\text {th }}$ ed. Belmont, California: Wadsworth Cengage learning.

Burke, S. (2008). Fashion entrepreneur. starting your own fashion business. Ringwood: Burke Publishing.

Burns, P. (2007). Entrepreneurship and small business. $2^{\text {nd }}$ ed. New York: Palgrave Macmillan.

Chapman, E.N. (1987). How to develop a positive attitude. Los Altos, California: Kogan Page.

Coertze, D.J. (1999). Research methodology: a hands-on approach to problem solving. Pretoria: Van Schaik.

Cooper, A. C., Gimeno-Gascon, F. J., \& Woo, C. Y. (1994). Initial human and financial capital as predictors of new venture performance. Journal of Business Venturing, 9,371-395.

Creswell, J.W. (2009). Research design qualitative, quantitative and mixed methods approaches. $3^{\text {rd }}$ ed. Thousand Oaks, California: Sage Publications, Inc.

Cronje, G.J., Du Toit, G.S. \& Motlatla, M.D.C. (2001). Introduction to business management. Cape Town: Oxford University Press.

Deamer, I. \& Earle, L. (2004). Searching for entrepreneurship. Industrial and Commercial Training, 36, 99-103.

Delport, C.S.L. (2005). Quantitative data collection methods. In De Vos, A.S., Strydom, H., Fouche, C.B. \& Delport C.S.L. Research at grass roots: for the social sciences and human services professions. 3rd ed. Pretoria: Van Schaik Publishers. pp. 159-191.

Ehigie, B. O. \& Umoren, U. E. (2003). Psychological factors influencing perceived entrepreneurial success among Nigerian women in small-scale businesses. Journal of International Women's Studies, 5, 78-95.

Fatt, J.P.T. (2001). Encouraging fashion entrepreneurship in Singapore. Journal of Marketing and Logistics, 13, 72-83.

Fink, M., Harms, R. \& Kraus, S. (2008). Cooperative internationalization of SMEs: self-commitment as a success factor for international entrepreneurship. European Management Journal, 26, 429-440.

Granger, M. \& Sterling, T. (2003). Fashion entrepreneurship: retail business planning. New York: Fairchild Publications.

Kingdon, G. \& Knight, J. (2004). Unemployment in South Africa: a micro economic approach. [Online] Available: $<$ http://www.csae.ox.ac.uk> (September 28, 2010)

Krauss, S.I., Frese, M. \& Friedrich, C. (2005). Entrepreneurial orientation: a psychological model of success among Southern African small business owners. European Journal of Work and Organizational Psychology, 14, 315-344.

Kurakto, D.F. (2009). Introduction to entrepreneurship. th $^{\text {th }}$ ed. Australia: South-Western.

Littunen, H. (2000). Entrepreneurship and the characteristics of the entrepreneurial personality. International Journal of Entrepreneurial Behavior and Research, 6, 295-309.

Llewellyn, D.F. \& Wilson, K.M. (2003). The controversial role of personality traits in entrepreneurial psychology. Education and Training, 45, 314-345.

Maree, K. \& Van der Westhuizen, C. (2007). Planning a research proposal. In Maree, K.(ed). First steps in research. Pretoria: Van Schaik.

Marshall, S.G., Jackson, H.O., Stanley, M.S., Kefgen, M. \& Touche-Specht, P. (2000). Individuality in clothing selection and personal appearance. $5^{\text {the }}$. New Jersey: Prentice Hall.

Martin, D. T. (1979). Alternative views of Mengerian entrepreneurship. History of Political Economy 11,271-285.

Mc Carthy, B. \& Leavy, B. (1999). The Entrepreneur, Risk Perception and Change over Time: A Typology Approach. Irish Business and Administrative Research, 20,126-140.

Mc Daniel, B.A. (2002). Entrepreneurship and innovation: an economic approach. New York: N.E. Sharpe, Inc.

Merrett, C.D. \& Gruidl, J.J. (2000). Small business ownership Illinois: the effect of gender and location on entrepreneurial success. Professional Geographer, 52,425-436.

Mete, F. (2006). The creative role of source of inspiration in clothing design. International Journal of Clothing Science and Technology, $18,278-293$. 
Mitchell, B.C. (2004). Motives of entrepreneurs: a case study of South Africa. The Journal of Entrepreneurship, 13,167-183.

Nieman, G., Hough, J. \& Nieuwenhuizen, C. (2003). Entrepreneurship: a South African perspective. Pretoria: Van Schaik.

North, E. (2002). A decade of entrepreneurship education in South Africa. South African Journal of Education, 22, 24-27.

Olson, D.E. (2000). The role of entrepreneurial personality characteristics on entry decisions in a simulated market. California State University at Bakersfield.

Paksoy, H. \& Yalcin, S. (2005). Architectural inspirations in fashion design. In $3^{\text {rd }}$ International symposium of interactive media design, 1 9, January. [Online] Available: <http://newmedia.yeditepe.edu.tr/pdfs/isimd_05/04.pdf> (April 28, 2009)

Prakash, A. \& Ouma, J. A. (2013). Do genetic traits of humans influence approaches to entrepreneurship: a comparative study of Asian origin entrepreneurs in Kenya and native Kenyan businessmen. International Journal of Organization Theory and Behavior, 16, 94-115.

Rogerson, C.M. (2006). Fashion and the growth of 'African' brands in South Africa. African Clothing \& Footwear Research, 1, 1-63.

Scarborough, N.M. \& Zimmerer, T.W. (2003). Effective small business management: an entrepreneurial approach. Upper Saddle River, New Jersey: Prentice Hall.

Shane, S., Locke, E.A. \& Collins, C.J. (2003). Entrepreneurial motivation. Human Resource Management Review, 13,257-279.

Silverman, D. (1970). The theory of organizations. London: Heinemann.

Sinha, P. (2002). Creativity in fashion. Journal of Textile and Apparel Technology and Management, 2, 1-16.

Smit, L. (2000). Entrepreneurship business management. $5^{\text {th }}$ ed. Cape Town: CLS Publishers.

Turner, S. (2005). Nascent market capitalism under question: interpretations of success among Makassar entrepreneurs. Cultural Studies, 96,264-274.

Vallone, A.M. (2008). A study of the success and failure of apparel entrepreneurs. Auburn: Alabama University.

Van Gelderen, M., Thurik, R. \& Bosma, N. (2005). Success and risk factors in the pre-start-up phase. Small Business Economics, 24,365-380.

Van Praag, M.C. (2003). Business survival and success of young small business owners. Small Business Economics, 21, 1-17.

Van Wyk, A.W. (2007). Small fashion owners and their businesses in the Vaal region. MTech dissertation. Vaal University of Technology: Vanderbijlpark.

Vazquez-Carrasco, R., Lopez-Perez, M.E. \& Centeno, E. (2011). A qualitative approach to the challenges for women in management: are they really starting in the $21^{\text {st }}$ century? Qual Quant, Science and Business Media, 1-21.

Ward, T.B. (2004). Cognition, creativity and entrepreneurship. Journal of Business Venturing, 19,173-188.

Yueh, L. (2009). China's entrepreneurs. World Development, 37,778-786. 